\title{
MANAJEMEN PERPUSTAKAAN DI MADRASAH ALIYAH NEGERI YOGYAKARTA
}

\author{
Suhaemin, Suharsimi Arikunto \\ MTsN Tempel Sleman, Universitas Negeri Yogyakarta \\ eminmukmin@gmail.com, ari_uny@yahoo.com
}

\begin{abstract}
Abstrak
Penelitian ini bertujuan untuk mengetahui manajemen perpustakaan di tiga MAN Yogyakarta yang meliputi aspek perencanaan, pengorganisasian, pelaksanaan, dan pengawasan. Mengetahui hambatan yang muncul dalam proses manajemen perpustakaan di tiga MAN Yogyakarta, dan mengetahui upaya yang dilakukan mengatasi hambatan yang muncul dalam manajemen perpustakaan di tiga MAN Yogyakarta. Pendekatan yang digunakan dalam penelitian ini adalah kualitatif deskriptif. Subyek penelitian adalah kepala madrasah, petugas perpustakaan, guru, dan siswa. Hasil penelitian bahwa manajemen perpustakaan di tiga MAN Yogyakarta meliputi: a. Perencanaan berupa pengadaan buku setiap tahun. $b$. Pengorganisasian perpustakaan MAN Y I berada di wakamad humas, MAN Y II berada di bawah wakamad kurikulum dan MAN Y III berada di bawah kepala madrasah. c. Pelaksanaan mencakup pengadaan, pengolahan, pelayanan dan pembinaan. d. Pengawasan dilakukan kepala madrasah langsung datang ke perpustakaan. Hambatannya sarana perpustakaan dan minat baca siswa kurang. Upaya dilakukan menambah sarana ruang baca, dan memberi tugas siswa di perpustakaan.
\end{abstract}

Kata kunci: manajemen, perpustakaan

\section{THE MANAGEMENT OF LIBRARIES AT MADRASAH ALIYAH NEGERI YOGYAKARTA}

\begin{abstract}
This study aims to investigate the library management in three in MANs in Yogyakarta in terms of the aspects of planning, organizing, actuating, and controlling, the constraints appearing in the process of the library management in the three schools, and the attempts made to deal with the constraints. The study employed the qualitative approach using the case study method. The research subjects comprised the principals, library personnel, teachers, and students. The results of the study on the library management in three MANs in Yogyakarta are as follows. a) The planning is in the form of the book procurement every year. b) The organization of the library of MAN Yogyakarta I is under the vice principal in charge of public relations, that of MAN Yogyakarta II is under the vice principal in charge of the curriculum, and that of MAN Yogyakarta III is under the principal. c) The actuation includes procurement, processing, services, and guidance. d) The control is carried out by the principal through a direct visit to the library. The constraints include the lack of infrastructure facilities and students' reading interest. The attempts made include adding a facility of a reading room and giving the students assignments in the library.
\end{abstract}

Keywords: management, library 


\section{Pendahuluan}

Sejak lama telah dikenal sebuah ungkapan "perpustakaan adalah jantungya ilmu pengetahuan". Bila pendidikan diibaratkan dengan badan, maka perpustakaan adalah jantungnya. Bila perpustakaan sehat maka sehat pulalah pendidikannya (Priyono, 2006: vii). Sebuah ungkapan yang telah terabaikan begitu saja. Adalah sangat ironis bila di dunia pendidikan sebagai sentra ilmu pengetahuan ternyata kurang atau bahkan tidak peduli sama sekali dengan keberadaan perpustakaan.

Sebenarnya, pengelolaan perpustakan bukanlah persoalan yang baru namun banyak orang yang salah meng-asosiasikan perpustakaan dengan buku-buku. Sehingga setiap tumpukan buku di suatu tempat disebut perpustakaan (Bafa-dal, 2009: 1). Memang perpustakaan memiliki salah satu ciri utama dengan adanya banyak buku namun bukan berarti setiap ada penumpukan buku lalu dapat dikatakan sebagai perpustakaan. Perpustakaan memiliki arti lebih spesifik yakni sebuah ruang khusus dengan tata kerja yang khusus pula.

Banyak permasalahan yang dihadapi petugas perpustakaan dalam mengelola perpustakaan. Persoalan klasik yang selalu ditemui dalam pengelolaan perpustakaan yakni dana pengelolaan dan perhatian yang kurang, terutama dari pemerintah. Hal inilah yang mengakibatkan beberapa perpustakaan hidup segan mati tak mau. Hal seperti itu juga dapat dilihat pada fenomena sebagai berikut: 1) Rendahnya persentase anggaran yang dialokasikan untuk perpustakaan; 2) Rendahnya perencanaan program pengembangan perpustakaan, implementasi dan evaluasi; 3) Kurangnya upaya pemerintah mencari pendanaan perpustakaan; 4) Lemahnya upaya pengintegrasian pelayanan perpustakaan dengan kurikulum sekolah (Siregar, 2004: 10-11).

Banyak kalangan di dunia pendidikan yang seharusnya bertanggung jawab dengan keberadaan perpustakaan tetapi malah melupakan tanggung jawab tersebut. Misalnya, pada penyusunan Ren- cana Anggaran Pendapatan dan Belanja Sekolah (RAPBS), alokasi dana untuk perpustakaan sekolah sering terabaikan. Kalaupun ada hanya sebatas honor untuk petugas pustaka, sedangkan alokasi dana untuk penambahan koleksi, pemeliharaan koleksi dan pemeliharaan sarana pustaka lainnya belum mendapat perhatian.

Di sekolah/madrasah negeri pada umumnya, tugas di perpustakaan dianggap sebagai tugas tambahan bagi seorang guru yang kurang jam mengajar sehingga tidak perlu diberi insentif khusus untuk tugas tambahannya itu. Akibatnya, pengelolaan perpustakaan kurang maksimal dan cenderung pengelolaannya kurang terfokus. Sehingga perpustakaan yang dikelola hanya menjadi gudang buku, gedung peralatan dan peralatan lainnya, jarang dibuka apalagi melayani para penggunanya. Padahal bila dikelola dengan baik, perpustakaan di sekolah sangat membantu proses belajar mengajar karena perpustakaan dapat dijadikan pusat kegiatan belajar mengajar, pusat penelitian sederhana, pusat membaca, bahkan dapat dijadikan tempat rekreasi siswa. Beberapa penelitian telah membuktian peran penting perpustakaan dalam dunia pendidikan, seperti peran perpustakaan terhadap minat baca, dan peran perpustakaan terhadap prestasi belajar.

Pada Kepmen PAN No. 18 Tahun 1988, pemerintah sendiri telah memberikan perhatiannya terhadap keberadaan perpustakaan di sekolah-sekolah. Khusus untuk tenaga pengelola perpustakaan berstatus Pegawai Negeri Sipil digolongkan kepada tenaga fungsional yang mendapat tunjangan khusus (Sutarno, 2003: 8).

Dalam Undang-undang Pendidikan Nomor 20 (Undang-undang, 2003) disebutkan bahwa: Standar Nasional Pendidikan terdiri atas standar isi, proses, kompetensi lulusan, tenaga kependidikan, sarana dan prasarana, pengelolaan, pembiayaan, dan penilaian pendidikan, yang harus ditingkatkan secara berencana dan berkala (Pasal 35: 1).

Selanjutnya pasal ini diperjelas dengan (Pasal 42: 2) yang berbunyi: Setiap 
satuan pendidikan wajib memiliki prasarana yang meliputi, lahan, ruang kelas, ruang pimpinan satuan pendidikan, ruang pendidik, ruang tata usaha, ruang perpustakaan, ruang laboratorium, ruang bengkel kerja, ruang unit produksi, ruang kantin, instalansi daya dan jasa, tempat olah raga, tempat beribadah, tempat ber-main, tempat rekreasi, dan ruang tempat lain yang dibutuhkan untuk menunjang proses pembelajaran yang teratur dan berkelanjutan.

Ternyata pemerintah cukup tegas dengan keberadaan perpustakaan di sekolah. Perpustakaan bukan berarti boleh ada boleh tidak bagi sebuah sekolah, tapi wajib ada. Realitanya, bila keberadaan perpustakaan di sekolah saja belum dapat perhatian dari pihak sekolah, apalagi untuk koleksi perpustakaan tentu tidak dapat berharap banyak. Padahal untuk koleksi perpustakaan, layaknya jumlah buku bacaan yang dikoleksi sebanding dengan jumlah siswa yang ada seperti telah dinyatakan dalam Standar Pendidikan Nasional bahwa "standar buku perpustakaan dinyatakan dalam jumlah judul dan jenis buku di perpustakaan di satuan pendidikan" (Pasal 43: 3, PP RI No. 19 Thn, 2005)

Rasio ideal jumlah buku di perpustakaan sekolah digambarkan bahwa, koleksi buku perpustakaan SD di Indonesia rasionya satu anak berbanding dengan lima buku saja sudah cukup baik. Bila ditinjau dari isinya, idealnya perpustakaan di sekolah berisi buku pendamping pelajar-an dan yang dibutuhkan anak untuk menunjang kegiatan belajar-mengajar. Namun demikian, sekolah tidak perlu ragu untuk menarik minat baca anak dengan menyediakan buku fiksi, komik dan cerita rakyat yang bernilai positif. Sedangkan untuk Sekolah Tingkat Pertama, sebaiknya satu siswa berbanding 12 judul buku. Bila siswa berjumlah 700 orang, berarti idealnya minimal memiliki 8.400 judul buku bacaan. Inilah yang sering tidak terpenuhi.

Rendahnya minat baca juga menjadi kendala bagi pengelola perpustakaan. Masyarakat Indonesia lebih dikenal sebagai masyarakat lisan daripada tulisan, sehingga akan dijumpai orang-orang yang suka ngobrol daripada membaca. Masyarakat lebih menyukai gosip dari pada fakta.

Dalam pengelolaannya, sebuah perpustakaan membutuhkan tenaga pengelola yang profesional agar dapat berfungsi secara optimal. Dengan demikian, karena pengelolaan perpustakaan bukanlah pekerjaan yang ringan. Pengelolaan perpustakaan memerlukan orang yang memahami perpustakaan, cara kerja, manajemennya, dan yang paling utama haruslah orang-orang yang mencintai buku, bahwa pustakawan bukanlah profesi yang sembarangan, pustakawan sama pentingnya dengan profesi dokter dan guru yang memiliki peranan dan jasa mulia. Sayangnya, masyarakat kita tidak akrab dengan perpustakaan bahkan ada yang tidak mengenal perpustakaan apalagi kenal dengan profesi pustakawan.

Selain pengetahuan tentang perpustakaan, seorang pengelola perpustakaan sebaiknya juga mampu mengelola perpustakaan itu dengan baik. Manajemen tersebut meliputi penyusunan program kerja dan program pengembangan, melaksanakan program seperti penataan sarana dan peralatan, pengadaan koleksi, pengolahan, sirkulasi, pelayanan, dan pembinaan, serta melaksanakan pengawasan. Tidak hanya duduk diam saja, atau malah jarang membuka perpustakaan. Oleh karena itu, penulis tertarik ingin mengetahui keberadaan perpustakaan yang ada di madrasah-madrasah negeri yang ada di Yogyakarta, baik yang berstatus sudah baik atau belum, dalam arti lain, peneliti ingin mengetahui pengelolaan perpustakaan di madrasah-madrasah tersebut.

Di Yogyakarta ada 3 Madrasah Aliyah Negeri Yogyakarta (MAN Y), yaitu Madrasah Aliyah Negeri Yogyakarta I, Madrasah Aliyah Negeri Yogyakarta II, dan Madrasah Aliyah Negeri Yogyakarta III. Masing-masing ketiganya sudah terakreditasi A dan sudah mendapatkan predikat yang baik serta sudah mendapatkan penghargaan banyak. Namun apakah dari segi manajemen/pengelolaan perpustakaan masing-masing sudah terlaksana de- 
ngan baik dan sesuai dengan standar perpustakaan sekolah.

Oleh sebab itu, dari tiga tempat tersebut, tidak lain hanya untuk mengetahui proses manajemen/pengelolaan perpustakaan dari masing-masing madrasah tersebut. Selain itu, juga ingin mengetahui apakah perpustakaan dari ketiganya sudah sesuai dengan standar pengelolaan perpustakaan yang sudah ada. Dalam peraturan pemerintah tahun 2007 Nomor 19 disebutkan bahwa pengelolaan perpustakaan sekolah/madrasah perlu: 1) menyediakan petunjuk pelaksanaan operasional peminjaman buku dan bahan pustaka lainnya; 2) merencanakan fasilitas peminjaman buku dan bahan pustaka lainnya sesuai dengan kebutuhan peserta didik dan pendidik; 3) membuka pelayanan minimal enam jam sehari pada hari kerja; 4) melengkapi fasilitas peminjaman antar perpustakaan, baik internal maupun eksternal; 5) menyediakan pelayanan peminjaman dengan perpustakaan dari sekolah/madrasah lain baik negeri maupun swasta.

Salah satu pengelolaan perpustakaan yang paling urgen adalah pengelolaan buku. Koleksi buku-buku perpustakaan di madrasah, salah satunya di MAN Y I yang peneliti pernah berkunjung, terdapat masih kebanyakan buku-buku pelajaran, sedangkan buku-buku penunjang seperti buku non pelajaran/fiksi masih sedikit dan perlu ditambah. Dari segi sarana prasarana juga kurang, terutama ruang baca yang seringkali peneliti melihat di waktu jam istirahat terlalu padat, sehingga kurang efektif dan efisien ketika membaca. Selain itu, dari segi tenaga perpustakaan yang benar-benar dari jurusan perpustakaan yaitu cuma satu orang. Artinya dari segi tenaga yang profesional di perpustakaan MAN Y I masih perlu ditambah. Selanjutnya di MAN Y II, pegawai atau staf perpustakaan semuanya tidak ada yang jurusan pendidikan keperpustakaan. Bahkan kepala perpustakaan sendiri S1nya dari jurusan ekonomi. Kursi dan peralatan yang ada di perpustakaan tersebut terlihat baik, namun ada sedikit tidak terawat dengan baik, karena masih banyak debu dan kotoran di atasnya. Se- dangkan di MAN Y III, pengelolaan perpustakaan secara keseluruhan sudah baik, tetapi ada sebagian staf atau pegawai perpustakaan yang latar belakangnya bukan dari pendidikan perpustakaan, selain itu ruang Audio visual dan E-Library masih belum optimal, karena didapati belum dioperasionalkan. Berdasarkan latar belakang di atas, maka penelitian tentang "Manajemen Perpustakaan di tiga MAN Yogyakarta" penting dilakukan.

Identifikasi permasalahan yang berkaitan dengan manajemen perpustakaan di tiga MAN Yogyakarta sebagai berikut: 1) Perpustakaan belum dikelola berdasarkan prinsip manajemen; 2) Petugas perpustakaan madrasah masih banyak yang berlatar belakang bukan dari pendidikan perpustakaan; 3) Koleksi perpustakaan madrasah masih tergolong kurang, dari segi koleksi buku penunjang bukan koleksi buku pelajaran; 4) Sarana dan prasarana terutama gedung masih belum memadai; 5) Pemanfaatan perpustakaan bagi siswa belum terlayani dengan baik.

Bagi sebuah organisasi, manajemen merupakan kunci sukses karena sangat menentukan kelancaran kinerja organisasi yang bersangkutan. Menurut Daft (1991) "Manajemen is the attainment of organizational goals in an effective and efficient manner through planning, organizing, leading, and controlling organizational resources", yaitu manajemen adalah pencapaian tujuan organisasi secara efektif dan efisien melalui perencanaan, pengorganisasian, kepemimpinan, dan pengendalian sumber daya organisasi. Perpustakaan sebagai salah satu ruang lingkup manajemen pendidikan perlu dikelola dengan efektif dan efisien untuk mencapai tujuan.

\section{Metode Penelitian}

Jenis penelitian

Pendekatan yang digunakan dalam penelitian ini adalah kualitatif dengan metode studi kasus di tiga MAN Yogyakarta, yaitu menggambarkan keadaan dan memecahkan masalah yang sedang berlangsung. Dengan pendekatan ini diharapkan peneliti 
dapat menghasilkan data yang deskriptif yang dapat dituangkan dalam bentuk laporan dan uraian, jadi tidak diutamakan angka-angka statistik.

\section{Tempat dan Waktu Penelitian}

Tempat yang digunakan dalam penelitian ini adalah di tiga perpustakaan madrasah, dengan perinciannya yaitu perpustakaan MAN Yogyakarta I, perpustakaan MAN Yogyakarta II dan perpustakaan MAN Yogyakarta III. Waktu penelitian ini dilaksanakan kurang lebih selama enam bulan. Dimulai bulan November 2012 sampai dengan bulan April 2013.

\section{Traget/Subjek Penelitian}

kepala madrasah selaku penanggung jawab madrasah dan juga sebagai pengawas terhadap perpustakaan. Kkepala perpustakaan selaku penanggung jawab pelaksanaan kegiatan-kegiatan di perpustakaan dapat dimintai keterangan tentang pelaksanaan manajemen perpustakaan, serta berbagai macam sarana dan prasarana yang digunakan sebagai penunjang pelaksanaan pengelolaan perpustakaan yang efektif. Sedangkan guru dan siswa sebagai pemakai perpustakaan.

Teknik dan Instrumen Pengumpulan data

Observasi yang dilakukan yaitu melalui cara pengamatan yang tidak berperan serta. Artinya peneliti hanya mengadakan pengamatan saja tanpa menjadi anggota kelompok yang diamatinya.

Wawancara yang dilakukan peneliti di tiga MAN Yogyakarta dimaksudkan untuk mengumpulkan data, berdialog dengan informan. Wawancara mendalam dilakukan terhadap seluruh unsur, yaitu kepala madrasah, kepala perpustakaan, guru dan siswa.

Dokumentasi yang dimaksud adalah berupa foto-foto selama peneliti mengadakan penelitian di tiga MAN Yogyakarta. Dari foto tersebut peneliti dapat memperoleh data yang diperlukan. Selain itu, peneliti juga memperoleh data berupa daftar murid kelas X sampai kelas XII yang ada di perpustakaan.

\section{Instrumen Pengumpulan Data}

Instrumen dalam penelitian ini adalah peneliti sendiri. Peneliti sebagai instrumen terjun langsung dalam pengambilan data dengan alat bantu berupa lembar observasi, pedoman wawancara dan catatancatatan dokumen yang ada di madrasah.

\section{Keabsahan Data}

Dalam penelitian ini pemeriksaan keabsahan data menggunakan teknik: Keikutsertaan di lapangan dalam rentang waktu enam bulan lebih dalam rentang waktu yang panjang untuk menguji kepercayaan terhadap data yang telah dikumpulkan dari informan, maka perlu mengadakan keikutsertaan dalam rentang waktu yang lebih panjang dan lama.

\section{Teknik Analisis Data}

Dalam penelitian kualitatif, peneliti akan mendapatkan data beranekaragam yang berasal dari berbagai macam sumber, yaitu: observasi, wawancara ataupun dokumen. Agar hasil penelitian sesuai yang diharapkan dan cocok dengan pendekatan kualitatif, maka teknik analisis data yang digunakan adalah pendekatan induktif artinya pemecahan masalah didasarkan atas berfikir empiris melalui data dan fakta yang diperoleh di lapangan.

Secara rinci analisis data akan dilakukan sebagai berikut, reduksi data yaitu menurut Sugiyono (2012: 92) Mereduksi data berarti merangkum, memilih hal-hal yang pokok, memfokuskan pada hal-hal yang penting, dicari tema dan polanya. Data mentah yang diperoleh dari observasi, wawancara dan dokumentasi kemudian diproses dan disusun dalam bentuk uraian yang kemudian direduksi, dirangkum, diseleksi atau dipilih yang penting, kemudian dicari kesimpulannya. Penyajian data, dan penarikan kesimpulan dilakukan secara bertahap, pertama berupa kesimpulan sementara, namun dengan bertambahnya data maka perlu dilakukan verifikasi 
data yaitu dengan mempelajari kembali data-data yang ada. Disamping itu, dilakukan dengan cara meminta pertimbangan dengan pihak-pihak yang berkenaan dengan penelitian ini yaitu kepada kepala madrasah, petugas perpustakaan, guru dan siswa.

\section{Hasil Penelitian}

\section{Sejarah MAN Yogyakarta}

Profil Madrasah Aliyah Negeri Yogyakarta (MAN Y) I

Madrasah Aliyah Negeri Yogyakarta I berdiri tahun 1950 dengan nama SGHA (Sekolah Guru Hakim Agama), waktu itu kepala madrasahnya bapak M. Saketi. Tahun 1954 berubah menjadi PHIN (Pendidikan Hakim Islam Negeri). Kemudian tahun 1987 berubah menjadi MAN Y I sampai sekarang. Kepala MAN Y I tahun 2013 sampai sekarang yaitu oleh Bapak Imam Suja'i Fadli M.Pd.I.

Secara geografis letak MAN Y I dapat diuraikan sebagai berikut: Sisi utara berbatasan dengan jalan Sekip Universitas Gadjah Mada, sisi barat berbatasan dengan kampus Universitas Gadjah Mada (FISIPOL), sisi selatan berbatasan dengan jalan kampung terban dan sisi timur berbatasan dengan jalan simanjutak.

Luas tanah madrasah MAN Y I yaitu $10027 \mathrm{~m}^{2}$, di atasnya bangunan gedung madrasah seluas $8367 \mathrm{~m}^{2}$, pagarnya seluas $380 \mathrm{~m}^{2}$, dan halamannya 797,5 $\mathrm{m}^{2}$. Adapun jumlah guru MAN Y I sebanyak 60, dengan perincian 26 guru laki-laki dan 34 perempuan. Sedangkan jumlah tenaga administrasi MAN Y I sebanyak 24 terdiri dari 17 tenaga putra dan 7 tenaga putri. Siswa yang masuk tahun ajaran 2012/2013 sebanyak 229 siswa. Jumlah total keseluruhan siswa tahun 2013 sebanyak 719 siswa.

Perpustakaan MAN Y I telah memiliki gedung sendiri yang didirikan pada tahun 1991, yang diresmikan oleh Kepala Kantor Wilayah Departemen DIY tepatnya pada tanggal 13 April 1991. Sebelumnya ruang perpustakaan berpindah-pindah.
Perpustakaan MAN Y I menempati satu gedung berlantai dua di samping bangunan sekolah berdampingan dengan masjid Al-Hakim MAN Y I dan gedung laboratorium bahasa serta fisika.

\section{Profil Madrasah Aliyah Negeri Yogyakarta (MAN Y) II}

Sejarah berdirinya MAN Y II adalah pada tahun 1979 yang semula dengan nama Pendidikan Guru Agama Negeri (PGAN). MAN Y II terletak di tengahtengah kota dan di pinggir jalan besar yaitu jalan K.H. Ahmad Dahlan, dengan luas tanah $3.685 \mathrm{~m}^{2}$, tidak memungkinkan untuk diperluas, hanya bisa menambah lokal ke atas karena kondisi fisiknya sangatlah sempit. Kepala MAN Y II sejak tahun 2013 dipimpin oleh Drs. H. Paimin, MA. Kondisi lingkungan belajar yang terjadi pada MAN Y II sangatlah tidak mendukung karena lingkungan madrasah yang sempit dan terletak di pinggir jalan sehingga sangatlah mengganggu terhadap aktifitas kegiatan belajar mengajar.

Jumlah guru MAN Y II sebanyak 56 guru, sedangkan Tenaga Adminsistrasi/ TU sebanyak 14 tenaga TU. Siswa yang masuk pada tahun ajaran 2012/2013 sebanyak 219, secara total keseluruhan pada tahun 2013 siswa sebanyak 710.

Perpustakaan MAN Y II merupakan bagian dari MAN Y II yang berfungsi sebagai pusat informasi bagi segenap sivitas akademik dalam rangka pelaksanaan visi dan misi MAN Y II. Terkait dengan posisinya yang sangat penting dan strategis, sebagaimana dikatakan bahwa "perpustakaan merupakan jantungnya pendidikan", maka keberadaan perpustakaan akan ikut menentukan prestasi yang akan diraih institusinya. Perpustakaan MAN Y II terletak di lokal tengah, sehingga memudahkan pengguna perpustakaan untuk menjangkaunya. Perpustakaan MAN Y II mulai berdiri dan beroperasi pada 03 Januari 1995. 
Profil Madrasah Aliyah Negeri Yogyakarta (MAN Y) III

Cikal bakal Madrasah Aliyah Negeri Yogyakarta III (MAYOGA) adalah bermula tahun 1950 dengan nama SGAI (Sekolah Guru Agama Islam) putra, kemudian tidak berlangsung lama pada tahun 1951 berubah menjadi PGAN (Pendidikan Guru Agama Negeri), waktu itu kepala madrasahnya bapak Malikus Suparto. Dalam perkembangannya, MAN Y III untuk wilayah Daerah Istimewa Yogyakarta ditetapkan sebagai MAN MODEL tahun 1998 dengan SK Dirjen Binbaga Islam Departemen Agama RI No.E.IV / PP.00.6 / KEP /17.A / 98.

Lokasi MAN Y III berada di jalan Magelang Kilometer 4 sebelah selatan TVRI Yogyakarta. Luas tanah MAN Y III yaitu $8558 \mathrm{~m}^{2}$, dengan perincian gedung madrasah seluas $6268 \mathrm{~m}^{2}$ dan lapangan olah raga seluas $2290 \mathrm{~m}^{2}$. Adapun jumlah guru MAN Y III sebanyak 63, dengan perincian 56 guru tetap sedangkan 7 sebagai guru tidak tetap (GTT). Pegawai Tata Usaha (TU) MAN Y III berjumlah 26 dengan perincian 11 pegawai tetap dan yang 15 sebagai pegawai tidak tetap (PTT). Adapun jumlah total siswa tahun 2013 sebanyak 645 siswa.

Pada tahun 1985 embrio perpustakaan dibentuk dengan nama Perpustakaan PGAN. Perpustakaan menempati ruang 2,5x6 $\mathrm{m}^{2}$ dengan sistem tertutup (close access). Koleksinya berupa buku teks pelajaran siswa PGAN dan MIN/SD. Tahun 1990 berdasarkan keputusan Menteri Agama No. 64 tahun 1990 diubah menjadi MAN. Karena siswanya sebagian besar masih siswa PGAN, perpustakaan ini masih tetap disebut perpustakaan PGAN. Kemudian tahun 1992, dengan keputusan kepala madrasah (MAN) waktu itu, Drs. Budi Sudjodo, perpustakaan MAYOGA (MAN Yogyakarta 3) dinyatakan resmi didirikan. Tahun 1998 pada masa kepemimpinan Drs. M. Taslim, dengan tetap berlokasi di ujung selatan (belakang), perpustakaan diperluas dengan menambah ruang baca ukuran $7 \times 8$ $\mathrm{m}^{2}$, dilengkapi dengan rak-rak baru dan 32 study carrel, dikelola oleh 2 orang pegawai honorer.

April 2001 atas kebijakan kepala madrasah (Drs. H. Sukardi) perpustakaan MAYOGA dipindahkan ke lokasi strategis, menempati ruang berukuran $7 \times 8 \mathrm{~m}^{2}$, disertai penambahan rak, display, meja baca, dan koleksi yang amat pesat, terutama buku-buku fiksi dan bacaan populer. Sistem layanan perpustakaan diubah menjadi open access. Dalam perombakan besarbesaran struktur organisasi MAYOGA, perpustakaan ditempatkan langsung di bawah Kepala Madrasah, dengan nama lembaga: Urusan Pendayagunaan Perpustakaan, dipimpin oleh guru berprestasi dan berdedikasi tinggi, yang berkedudukan sejajar dengan Kepala Urusan lainnya. Pada saat inilah kepala madrasah mengeluarkan 18 langkah pendayagunaan perpustakaan. Langkah berani ini menarik perhatian Dirjen Binbaga Islam waktu itu, Drs. Husni Rahim, untuk berkunjung ke Perpustakaan MAYOGA.

April 2002 perpustakaan ditambah dengan 1 ruang lagi $\left(7 \times 8 \mathrm{~m}^{2}\right)$, yang difungsikan sebagai ruang referensi sekaligus ruang audio-visual sederhana dan dilengkapi dengan meja lesehan, TV, VCD player, serta koleksi referensi. Sementara itu, 2 ruang lama disatukan menjadi 1 ruang saja $\left(16 \times 7 \mathrm{~m}^{2}\right)$. Semua ruangan berAC. Pada saat inilah Menteri Pendidikan Nasional (waktu itu), Prof. Drs. H.A. Malik Fadjar, M.Sc berkenan berkunjung ke Perpustakaan MAYOGA.

Tahun 2003, toilet, gudang dan serambi baca diintegrasikan ke perpustakaan. Perpustakaan juga dilengkapi dengan beberapa komputer untuk siswa dan meja layanan sirkulasi. Jumlah AC pun ditambah (dari 2 menjadi 3) madrasah juga membangun tower internet, yang disiapkan untuk menyongsong era otomasi online, elibrary dan layanan akses browsing internet di perpustakaan bagi siswa. Di tahun 2004 kepala madrasah, Drs. Sri Suwartiyah, menambah fasilitas perpustakaan dengan membangun ruang pengolahan dan gudang. 
Pada tahun 2007, dengan dana block-grant yang cukup besar dilakukanlah penggantian sarana prasarana meja besar, pesawat TV (48 inci), penambahan komputer untuk akses internet siswa dan katalog online (otomasi), pembangunan area serba guna yang diberi nama Area Baca \& Diskusi Terbuka (ABADIKA) yang lebih memadai, dan ruang pengolahan buku ajar. Sampai saat ini Perpustakaan MAYOGA yang dikelola oleh 6 orang, dan selalu meningkatkan kenyamanan dan kualitas layanannya (termasuk didalamnya desaindekorasi ruang yang menarik), masih menjadi mitra andalan bagi guru dan siswa dalam meningkatkan mutu pembelajaran.

\section{Manajemen Perpustakaan}

Menurut Darmono (2007: 25), "hakikat manajemen secara sederhana pada dasarnya adalah mengoptimalkan kontribusi manusia, material, anggaran untuk mencapai tujuan organisasi". Istilah manajemen sudah sangat populer di berbagai bidang organisasi atau instansi baik formal maupun informal. Para ahli memberikan definisinya masing-masing sesuai dengan persepsi dan persfektif pemahamannya.

Kata manajemen berasal dari bahasa Bahasa Latin, yaiu dari asal kata manus yang berarti tangan dan agree yang berarti melakukan. Kata-kata itu digabung menjadi kata kerja manager yang artinya menangani. Managere diterjemahkan ke dalam Bahasa Inggris dalam bentuk kata kerja to manage, dengan kata benda management, dan manager untuk melakukan kegiatan manajemen. Akhirnya, management diterjemahkan ke dalam bahasa Indonesia menjadi manajemen atau pengelolaan (Husaini Usman, 2011: 5).

Pendapat para ahli mengenai fungsi-fungsi manajemen memiliki kesamaan dalam fungsi planning, organizing, dan controlling. Secara esensial fungsi-fungsi manajemen dapat dirangkum yaitu perencanaan, pengorganisasian, pelaksanaan dan pengawasan. Untuk memperjelas berikut ini dibahas tentang fungsi-fungsi pokok manajemen:

\section{Perencanaan}

Perencanaan penelitian disini mencakup, tujuan, aksi, sumber daya, standar target. Tujuan organisasi sebagai suatu pernyataan tentang keadaan yang organisasi bermaksud untuk merealisasikan dan sebagai pernyataan tentang keadaan di waktu yang akan datang dimana organisasi sebagai kolektifitas mencoba untuk menimbulkannya (Handoko, 2003: 109) Salah satu tujuan perpustakaan ketiga MAN Yogyakarta adalah bagaimana membuat siswa senang membaca, menjadikan membaca sebagai kebutuhan dan mempunyai gairah untuk mencari informasi di perpustakaa, juga sebagai penunjang pembelajaran siswa dan guru yang tujuannya untuk membuat siswa mau membaca sehingga pengetahuan dan wawasan mereka bertambah, selain itu ketiga perpustakaan MAN Yogyakarta menjadi perpustakaan sekolah terbaik; menyegarkan, mencerdaskan, mencerahkan dan melejitkan.

Adapun Aksi berarti kegiatan spesifik yang direncanakan untuk mencapai tujuan. Kegiatan yang selalu dilakukan oleh perpustakaan bervariasi. Variasi kegiatan tersebut bergantung kepada jenis perpustakaan dan ruang lingkup organisasinya. Namun pada dasarnya kegiatan inti di perpustakaan adalah pengadaan, pengolahan, pelayanan koleksi, sosialisasi dan pembinaan.

Sebuah rencana harus menspesifikasi jenis dan jumlah sumber daya yang diperlukan. Menspesifikasi sumber dayasumber daya mencakup tindakan penganggaran (Budgeting).

Pada dasarnya semua perpustakaan, apapun bentuknya, untuk dapat berjalan mengemban tugas dan fungsinya harus ditopang dengan ketersediaan biaya yang memadai. Setelah anggaran tersedia, yang harus diperhatikan adalah bagaimana mendayagunakannya dengan seefektif dan seefisien mungkin, sesuai dengan prosedur administrasi keuangan, tidak terjadi pemborosan, penyalahgunaan atau penyimpangan, dan perpustakaan secara pasti me- 
ngalami kemajuan sebagaimana diharapkan.

Sumber daya manusia di perpustakaan merupakan salah satu faktor atau pilar yang sangat penting. Oleh sebab itu harus selalu dikembangkan sesuai dengan kebutuan yang harus dipenuhi. Sumber Daya Manusia (SDM), di perpustakaan MAN Y I akan menambah tenaga perpustakaan yang sesuai dengan jurusannya. Adapun perpustakaan MAN Y II berkaitan dengan SDM rencananya akan terus selalu mengadakan diklat atau seminar untuk para pegawai perpustakaan, supaya ada peningkatan dalam pelayanan atau administrasi lainnya. Sedangkan perpustakaan MAN Y III karena pustakawannya sudah ada dua, maka hanya menempatkan guru/ pegawai madrasah yang peduli dan cakap dalam pengelolaan dan pengembangan perpustakaan, mengirimkan pengelola perpustakaan pada pelatihan tentang perpustakaan.

Pengembangan sumber daya manusia di perpustakaan dapat dilakukan dengan mengikutsertakan pada pelatihan. Pelatihan adalah usaha suatu organisasi merencanakan kegiatan untuk membantu sumber daya yang terdapat dalam organisasi agar memperoleh efektifitas dalam pekerjaan mereka yang sekarang atau yang akan datang melalui pengembangan skill, knowlegde, dan behaviour (Noe, 2005: 3).

Standar Ketiga perpustakaan madrasah tersebut sudah memiliki standar yang ingin dicapai atau pedoman sebagai acuan ingin menjadi seperti apa perpustakaan ke depannya yaitu dengan berpedoman dengan UU no 43 tahun 2007 tentang perpustakaan. Dalam Permendiknas No. 24 tahun 2007 disebutkan tentang Standar Sarana dan Prasarana bagian D: Ketentuan Sarana dan Prasarana No. 2 Ruang Perpustakaan dapat dijadikan standar fisik yang ingin dicapai oleh sekolah, misal perpustakaan SMA/MA sekurang-kurangnya memiliki buku 1 siswa perbandingannya 15 buku, kalau jumlah siswa 800 maka koleksi yang harus dimiliki yaitu 12.000 buku. Atau dapat menggunakan pedoman penyelenggaraan perpustakaan sekolah yang dikeluarkan oleh Perpustakaan Nasional R.I. pada tahun 1994 yaitu Perpustakaan Sekolah: Petunjuk untuk membina dan memelihara perpustakaan di sekolah. Kepala sekolah atau petugas perpustakaan dapat pula membuat sendiri standar perpustakaannya.

Kepala madrasah MAN Y I atau petugas perpustakaan mengatakan bahwa target perpustakaan adalah agar ada keinginan siswa sebanyak mungkin datang ke perpustakaan, supaya mereka bertambah ilmu atau pengetahuannya, jangan hanya mengandalkan ilmu dari para guru. Adapun target perpustakaan MAN Y II yaitu minimal mendapatkan juara ketika mengikuti lomba, dan siswa aktif berkunjung ke perpustakaan setiap hari supaya perpustakaan ramai dan bermanfaat. Sedangkan target perpustakaan MAN Y III menurut pak kepala madrasah yaitu supaya dapat merealisasikan semua program yang direncanakan. Tapi menurut petugas perpustakaan untuk waktu dekat ingin memilliki ruangan Audio visual dan ruangan e-Library.

\section{Pengorganisasian}

Pengorganisasian meliputi menetapkan apa saja tugas yang harus dilakukan, siapa yang melakukan, bagaimana tugas dikelompokkan, dan bagaimana semua tugas tersebut dikoordinasikan. Sebagai hasil dari pengorganisasian adalah pembentukan struktur organisasi (Stueart, 2002: 23).

Pengorganisasian perpustakaan ketiga tersebut terdiri dari kepala perpustakaan sebagai penanggung jawab dan dibantu para anggotanya di bawah bimbingan kepala madrasah. Pengorganisasian perpustakaan MAN Y I berada di Waka Humas. Sedang perpustakaan MAN Y II berada di bawah Waka Kurikulum dan Waka Sarana Prasarana. Adapun pengorganisasian perpustakaan MAN Y III berada langsung dibawah kepala madrasah, setara dengan Waka-waka. 


\section{Pelaksanaan}

Pelaksanaan dalam perpustakaan yang dimaksud di sini adalah pelaksanaan kerja (actuating) perpustakaan. Pelaksanaan kerja dari setiap unit organisasi mulai dari pimpinan hingga staf-stafnya. Inti manajemen memang kepemimpinan, tetapi manajemen juga harus bertanggung jawab terhadap pelaksanaan pekerjaan. Ini berarti manajemen tidak hanya memerintah tetapi juga melaksanakannya (Moenir, 2003: 175).

Pelaksanaan tugas tersebut dimulai dari perencanaan, pengadaan, inventarisasi, klasifikasi (katalogisasi, label buku, kartu buku, slip tanggal dan kantong buku), penyusunan, pelayanan, pembinaan, sampai kepada evaluasi. Pelaksanaan tugas-tugas dalam perpustakaan tersebut tentu sesuai dengan pembagian tugas kepada unit-unit organisasinya seperti telah dijelaskan pada bagian sebelumnya. Berdasarkan uraian tersebut, dapat pula disimpulkan bahwa kegiatan utama dari petugas perpustakaan adalah pengadaan, pengolahan, pelayanan dan pembinaan.

Pengadaan koleksi bahan pustaka ketiga perpusatakaan MAN Y I, MAN Y II dan MAN Y III berasal dari dana DIPA, Komite Sekolah dan sumbangan/wakaf wajib bagi kelas XII. Pengolahan koleksi bagi petugas perpustakaan MAN Y I langsung melakukan pengolahan koleksi ketika datang buku baru. Penyelesaian pengolahan mudah dan cepat karena saling kerja sama antar pegawai perpustakaan. Baik buku yang sudah dialas ataupun buku baru. Hal yang sama juga dilakukan petugas perpustakaan MAN Y II melakukan pengolahan apabila ada buku baru. Begitupun dengan MAN Y III yang telah melakukan pengolahan terhadap bukubuku baru dan memperbaiki buku-buku yang rusak. Pelayanan Perpustakaan MAN Y I selalu melayani pada jam istirahat, dengan cara siswa mengisi buku kunjungan, lalu mencari di komputer atau memilih langsung buku di rak. Buku yang diminati dibaca dalam ruangan. Bila hendak dipinjam bawa pulang, dicatatkan kepada petugas dengan menyerahkan kartu anggota/ peminjaman. Bila guru yang meminjam untuk dibawa pulang, buku cukup dicatatkan kepada petugas perpustakaan, lalu langsung boleh dibawa. Yang terkadang membuat petugas kerepotan adalah ketika meminjam secara bersamaan yang ingin minta didahulukan. Untuk ke depannya petugas perpustakaan akan memberikan pelayanan yang cepat dan menyenangkan serta penambahan jam agar siswa terlayani dengan baik.

Mengenai layanan perpustakaan MAN Y II, hampir sama yaitu dengan cara siswa mengisi buku kunjungan, lalu mencari di komputer atau memilih langsung buku di rak. Buku yang diminati dibaca dalam ruangan. Bila hendak dipinjam bawa pulang, dicatatkan kepada petugas dengan menyerahkan kartu anggota/peminjaman. Untuk pelayanan bagi siswa dibagi dua, pelayanan tahunan dan pelayanan harian. Untuk pelayanan harian yaitu dengan menggunakan kartu yang waktunya hanya satu minggu. Sedangkan pelayanan tahunan biasanya kolektif, artinya peminjamannya satu kelas diwakili satu orang. Yang biasanya dipinjem berupa buku-buku paket.

Hampir sama dengan perpustakaan keduanya, alur pelayanan di perpustakaan MAN Y III yaitu mencari buku melalui komputer atau langsung juga bisa, kalau sudah cocok, mendatangi ke petugas perpustakaan untuk dicatatkan ke dalam peminjaman. Dengan menggunakan kartu anggota.

Perpustakaan MAN Y I dibatasi maksimal 4 buku dalam satu minggu bagi per siswa, tetapi kalau untuk guru boleh lebih dari 4. Adapun perpustakaan MAN Y II maksimal peminjamannya hanya dibatasi 2 buku dalam seminggu. Sedang-kan perpustakaan MAN Y III hampir sama dengan MAN Y I yaitu maksimal 4 buku, kecuali bagi siswa yang masuk anggota MBL (Mayoga Books Lovers) peminjaman boleh lebih dari 4 yaitu sampai 6 buku.

Pembinaan masing-masing perpustakaan yaitu kalau untuk pengunjung terutama siswa dilakukan diawal masuk ketika MOS diperkenalkan tata cara 
menggunakan perpustakaan serta pembuatan sekaligus pemberitahuan dan pemberlakuan peraturan-peraturan di perpustakaan atau dengan cara pengarahan langsung secara lisan baik berupa teguran ataupun berupa anjuran kepada siswa yang datang ke perpustakaan. Pembinaan kepada pengguna lain seperti para guru hanya dalam berupa meminta kesadaran para guru atas arti pentingnya perpustakaan sekolah. Pembinaan terhadap petugas perpustakaan dilakukan oleh kepala sekolah langsung berupa arahan atau teguran-teguran kepada petugas perpustakaan dalam menjalankan tugasnya.

\section{Pengawasan}

Pengawasan dapat didefinisikan sebagai proses untuk "menjamin" bahwa tujuan-tujuan organisasi dan manajemen tercapai. Ini berkenaan dengan cara-cara membuat kegiatan-kegiatan sesuai yang direncanakan. Pada pokoknya pengawasan adalah kegiatan yang membandingkan atau mengukur apa yang sedang atau sudah dilaksanakan dengan kriteria, normanorma, standar atau rencana-rencana yang sudah ditetapkan sebelumnya.

Kepala MAN Y I menyatakan bahwa bentuk pengawasan yang dilakukan berupa datang ke perpustakaan dua atau tiga bulan sekali untuk melihat-lihat pengaturan letak buku apakah rapi atau tidak. Menurut petugas perpustakaan, pengawasan Kepala Sekolah berupa menanyakan bagaimana kondisi perpustakaan sekolah.

Sedangkan kepala MAN Y II menyatakan pengawasan berupa datang ke perpustakaan sebulan sekali atau lebih bergantung dari situasi dan waktu yang beliau miliki. Sedang petugas perpustakaan mengatakan ada pengawasan dari Kepala Sekolah, namun jarang sekali beliau lakukan. Kepala Sekolah hanya menanyakan apakah perpustakaan rapi atau tidak.

Adapun kepala MAN Y III menyatakan bahwa ada pengawasan harian berupa menyaksikan sendiri dan melihat daftar pengunjung. Sedang menurut petugas perpustakaan, pengawasan Kepala
Madrasah berupa melihat apakah buku sudah diberi katalog atau belum. Hanya itu saja.

\section{Kendala/Hambatan}

Kendala manajemen perpustakaan MAN Y I yang pertama adalah ruangan, terutama ruang baca. Mengingat pada jam istirahat ketika secara bersamaan siswa memakai ruangan menjadi padat dan ruangan menjadi kurang kondusif untuk membaca. Kedua, Pada saat hari efektif, pengunjung perpustakaan belum bisa terlayani dengan baik.

Perpustakaan MAN Y II telah memiliki ruangan sendiri. Kendala ada berupa: pertama, dari segi fisik bangunan, tempatnya kurang strategis soalnya berada di lantai dua dan tempatnya agak jauh dari ruang kelas. Kedua minat baca siswa sangat kurang, dan yang ketiga petugas perpustakaan istilahnya belum ada yang dari jurusan perpustakaan. Sedangkan petugas perpustakaan mengatakan, kendalanya dari segi pemakai terutama siswa rendah, kemudian bapak ibu guru juga kurang banyak memanfaatkan, hanya sebatas buku paket. Selanjutnya adalah kendala birokrasi kita harus melewati dua orang atasan yang berbelit-belit. Kemudian dari petugasnya pun banyak yang belum tahu, kalaupun tahu hanya sekilas-sekilas saja. Bagaimana cara meningkatkan pelayanan, bagaimana meningkatkan manajerialnya itu yang belum banyak kami yang tahu.

Kendala manajemen perpustakaan MAN Y III yang pertama adalah kurangnya tenaga TIK, karena sering dipakai di tempat lain. Yang kedua, kurangnya kesadaran pemustaka/siswa untuk mengisi presensi pengunjung sehingga sangat banyak pengunjung yang tidak terhitung dalam laporan jumlah pengunjung. Yang ketiga kurangnya honor untuk para petugas yang sesuai dengan UMR.

\section{Upaya}

Upaya yang dilakukan selama ini yaitu; untuk tenaga perpustakaan yang bukan dari jurusan perpustakaan adalah 
dengan mengadakan diklat-diklat atau seminar tentang pengelolaan perpustakaan. Lalu untuk sarana perpustakaan yang belum optimal salah satunya ruang baca ditambah diluar ruang perpustakaan sebagai sarana ruang baca. Dan untuk honor pegawai yang belum UMR yaitu ditambah dengan uang nglembur. Yang terakhir kurangnya minat baca siswa, maka guru sering memberikan tugas kepada siswa yang bahan atau materinya hanya ada di perpustakaan.

\section{Pembahasan}

\section{Perencanaan}

Fungsi perencanaan yaitu mencakup empat elemen dasar: tujuan, aksi, sumber daya, standar dan target. Tujuan/Visimisi perpustakaan MAN Y I adalah "Ulil Albab" (Unggul, Ilmiah, Amaliah, Ibadah dan Bertanggung jawab), membuat siswa senang membaca, menjadikan membaca sebagai kebutuhan dan mempunyai gairah untuk mencari informasi di perpustakaan. Sedangkan visi-misi perpustakaan MAN Y II yaitu sebagai pusat informasi, penelitian dan pembelajaran, juga sebagai penunjang pembelajaran siswa dan guru yang tujuannya untuk membuat siswa mau membaca sehingga pengetahuan dan wawasan mereka bertambah. Adapun visi-misi perpustakaan MAN Y III adalah menjadi perpustakaan sekolah terbaik; menyegarkan, mencerdaskan, mencerahkan dan melejitkan, serta mengembangkan minat baca siswa untuk menambah wawasan siswa. Selain itu bertujuan untuk mengembangkan minat baca siswa sehingga pengetahuan dan wawasan mereka bertambah.

Pada dasarnya ketiga perpustakaan tersebut memiliki tujuan yang hampir sama, yakni menjadikan perpustakaan sebagai perpustakaan yang terbaik serta sebagai wahana yang mampu mengembangkan minat baca siswa agar senang membaca sehingga pengetahuan dan wawasan mereka bertambah.

Aksi berarti kegiatan spesifik yang direncanakan untuk mencapai tujuan. Ke- giatan ini mencakup pengadaan, pengolahan, pelayanan koleksi, sosialisasi dan pembinaan. Pengadaan koleksi bahan pustaka perpustakaan MAN Y I setiap tahunnya dari DIPA, Komite madrasah dan sumbangan wajib bagi siswa kelas XII. Rencana pembelian bahan-bahan koleksi terutama buku berdasarkan penyebaran kertas usulan para guru maupun karyawan yang diberikan diawal tahun sebelum pembelian. Hasil usulan yang terbanyak dijadikan sebagai patokan pembelian koleksi pustaka. Pengadaan koleksi perpustakaan MAN Y II adalah dari dana Komite madrasah, DIPA dan Sumbangan wakaf kelas XII berupa buku, kalau diuangkan antara 50 sampai 100 ribu. Akan tetapi perpustakaan MAN Y III pengadaan koleksinya bersumber dari Komite madrasah, DIPA, wakaf siswa kelas XI, peneliti, kedutaan besar Amerika Serikat, majalah lajnah Jakarta dan pensiunan guru.

Pengolahan di perpustakaan MAN Y I langsung dikerjakan ketika datang buku baru. Penyelesaian pengolahan mudah dan cepat karena saling kerja sama antar pegawai perpustakaan. Baik buku yang sudah diulas ataupun buku baru. Hal yang sama juga dilakukan petugas perpustakaan MAN Y II melakukan pengolahan apabila ada buku baru. Begitu juga dengan perpustakaan MAN Y III melakukan pengolahan terhadap buku-buku baru dan memperbaiki buku-buku yang rusak.

Pelayanan perpustakaan MAN Y I pada jam istirahat, dengan cara siswa mengisi buku kunjungan, lalu mencari di komputer atau memilih langsung buku di rak. Buku yang diminati dibaca dalam ruangan. Bila hendak dipinjam bawa pulang, dicatatkan kepada petugas dengan menyerahkan kartu anggota/peminjaman. Bila guru yang meminjam untuk dibawa pulang, buku cukup dicatatkan kepada petugas perpustakaan, lalu langsung boleh dibawa. Pelayanan perpustakaan MAN Y II, hampir sama yaitu dengan cara siswa mengisi buku kunjungan, lalu mencari di komputer atau memilih langsung buku di rak. Buku yang diminati dibaca dalam ruangan. Bila hendak dipinjam bawa pu- 
lang, dicatatkan kepada petugas dengan menyerahkan kartu anggota/peminjaman. Untuk pelayanan bagi siswa dibagi dua, pelayanan tahunan dan pelayanan harian. Untuk pelayanan harian yaitu dengan menggunakan kartu yang waktunya hanya satu minggu. Sedangkan pelayanan tahunan biasanya kolektif, artinya peminjamannya satu kelas diwakili satu orang, yang biasanya dipinjam berupa buku-buku paket. Adapun pelayanan perpustakaan MAN Y III ini mencakup beberapa kategori; 1) Peminjaman secara on line max 4 buku dalam satu minggu bagi per siswa, kecuali yang masuk anggota Mayoga Books Lovers (MBL) peminjaman boleh lebih dari 4 tapi max 6. 2) Peminjaman klasikal, model peminjaman ini misalkan murid meminjam buku pelajaran secara kolektif dalam satu kelas. 3) peminjaman buku paket yang waktunya satu tahun.

Sosialisasi untuk meningkatkan jumlah pengunjung, perpustakaan MAN Y I membuat rencana kegiatan berupa penugasan atau PR ke siswa untuk mencari informasi di perpustakaan. Kemudian memberikan reward atau hadiah kepada siswa yang aktif ke perpustakaan. Aktif di sini adalah meminjam, membaca dan menyimpulkan bacaannya, bukan hanya sekedar hadir. Cara perpustakaan MAN Y II meningkatkan jumlah pengunjung adalah dengan mengadakan sosialisasi ketika MOS. Yang kedua dengan memberikan reward bagi peminjam terbanyak. Sedangkan MAN Y III untuk meningkatkan pengunjung yaitu mengadakan sosialiasi di waktu MOS, lomba referensi (lomba yang paling banyak membaca buku diperpustakaan, tidak hanya buku pelajaran), mendesain tata ruang yang menarik dan nyaman, serta menyediakan berbagai macam koleksi.

Pembinaan masing-masing perpustakaan hampir sama yaitu kalau untuk pengunjung terutama siswa dilakukan pembuatan sekaligus pemberitahuan dan pemberlakuan peraturan-peraturan di perpustakaan atau dengan cara pengarahan langsung secara lisan baik berupa teguran ataupun berupa anjuran kepada siswa yang datang ke perpustakaan. Pembinaan kepada pengguna lain seperti para guru hanya dalam berupa meminta kesadaran para guru atas arti pentingnya perpustakaan sekolah. Pembinaan terhadap petugas perpustakaan dilakukan oleh kepala sekolah langsung berupa arahan atau teguran-teguran kepada petugas perpustakaan dalam menjalankan tugasnya.

Sumber daya di sini mencakup anggaran dan sumber daya manusia. Anggaran ketiga perpustakaan tersebut, baik MAN Y I, MAN Y II dan MAN Y III bersumber dari Komite madrasah, DIPA dan sumbangan siswa kelas XII. Sumber Daya Manusia (SDM) di perpustakaan MAN Y I akan menambah tenaga perpustakaan yang sesuai dengan jurusannya. Adapun perpustakaan MAN Y II rencananya akan terus selalu mengadakan diklat atau seminar untuk para pegawai perpustakaan. Sedangkan perpustakaan MAN Y III karena pustakawannya sudah ada dua, maka hanya menempatkan guru/pegawai madrasah yang peduli dan cakap dalam pengelolaan dan pengembangan perpustakaan serta mengirimkan pengelola perpustakaan pada pelatihan tentang perpustakaan.

Standar atau pedoman ketiga perpustakaan madrasah tersebut sudah memiliki sebagai acuan ingin menjadi seperti apa perpustakaan kedepannya, yaitu dengan berpedoman dengan UU no 43 tahun 2007 tentang perpustakaan. Dalam Permendiknas No. 24 tahun 2007 disebutkan tentang Standar Sarana dan Prasarana bagian D: Ketentuan Sarana dan Prasarana No. 2 Ruang Perpustakaan dapat dijadikan standar fisik yang ingin dicapai oleh sekolah, misal perpustakaan SMA/MA sekurang-kurangnya memiliki buku 1 siswa perbandingannya 15 buku, kalau jumlah siswa 800 maka koleksi yang harus dimiliki yaitu 12.000 buku. Atau dapat menggunakan pedoman penyelenggaraan perpustakaan sekolah yang dikeluarkan oleh Perpustakaan Nasional R.I. pada tahun 1994 yaitu, Perpustakaan Sekolah: Petunjuk untuk membina dan memelihara perpustakaan di sekolah. Kepala sekolah atau petugas perpustakaan dapat pula 
membuat sendiri standar perpustakaannya.

Target perpustakaan MAN Y I adalah agar ada keinginan siswa sebanyak mungkin datang ke perpustakaan, supaya mereka bertambah ilmu atau pengetahuannya, tidak hanya mengandalkan ilmu dari para guru. Adapun target perpustakaan MAN Y II yaitu minimal mendapatkan juara ketika mengikuti lomba, dan siswa aktif berkunjung ke perpustakaan setiap hari supaya perpustakaan ramai dan bermanfaat. Sedangkan target perpustakaan MAN Y III yaitu supaya dapat merealisasikan semua program yang direncanakan. Serta dalam waktu dekat ingin memilliki ruangan Audio visual dan ruangan $e$-Library.

Pengorganisasian

Pengorganisasian perpustakaan MAN Y I yakni ibu Sri Munarsih sebagai kepala perpustakaan. Kemudian bagian teknis terdiri; ibu Hera bagian pengolahan, pak Arifin bagian penyusunan. Sedangkan bagian pelayanan adalah Bapak Suharyadi, bagian Sirkulasi Ibu Siti Noor bagian referensi dan Siti Mutmainah bagian membaca. Perpustakaan MAN Y II terdiri dari pak Somadi sebagai kepala perpustakaan dengan pertimbangan rajin, teliti dan mudah bergaul dengan yang lainnya. Dibantu pak Amsori sebagai pelayanan teknis dan pak Eko Suryadi sebagai pelayanan pembaca. Organisasi perpustakaan MAN Y III terdiri dari ibu Rini Utami sebagai kepala perpustakaan, ibu Rodatun Widayati sebagai wakaur perpustakaan, dan dibantu para stafnya.

Pengorganisasian perpustakaan MAN Y I berada di Waka Humas. Sedang perpustakaan MAN Y II berada di bawah Waka Kurikulum. Adapun pengorganisasian perpustakaan MAN Y III berada langsung dibawah kepala madrasah, setara dengan Waka-waka lainnya.

\section{Pelaksanaan}

Pelaksanaan dalam perpustakaan yang dimaksud di sini adalah pelaksanaan kerja (actuating) dalam perpustakaan. Pelaksanaan kegiatan utama dari petugas perpustakaan adalah pengadaan, pengolahan, pelayanan dan pembinaan. Pengadaan koleksi bahan pustaka perpusatakaan MAN Y I, MAN Y II dan MAN Y III berasal dari dana DIPA, Komite Sekolah dan sumbangan/wakaf wajib bagi kelas XII. Pengolahan bahan koleksi perpustakaan MAN Y I dilakukan ketika datang buku baru dan buku yang sudah dialas. Hal yang sama juga dilakukan petugas perpustakaan MAN Y II melakukan pengolahan apabila ada buku baru. Begitu juga dengan MAN Y III melakukan pengolahan buku-buku baru dan memperbaiki buku-buku yang rusak. Pelayanan perpustakaan MAN Y I selalu melayani pada jam istirahat, dengan cara siswa mengisi buku kunjungan, lalu mencari di komputer atau memilih langsung buku di rak. Buku yang diminati dibaca dalam ruangan. Bila hendak dipinjam bawa pulang, dicatatkan kepada petugas dengan menyerahkan kartu anggota/peminjaman. Bila guru yang meminjam untuk dibawa pulang, buku cukup dicatatkan kepada petugas perpustakaan, lalu langsung boleh dibawa. Pelayanan perpustakaan MAN Y II, hampir sama yaitu dengan cara siswa mengisi buku kunjungan, lalu mencari di komputer atau memilih langsung buku di rak. Buku yang diminati dibaca dalam ruangan. Bila hendak dipinjam bawa pulang, dicatatkan kepada petugas dengan menyerahkan kartu anggota/peminjaman. Untuk pelayanan bagi siswa dibagi dua, pelayanan tahunan dan pelayanan harian. Untuk pelayanan harian yaitu dengan menggunakan kartu yang waktunya hanya satu minggu. Sedangkan pelayanan tahunan biasanya kolektif, sistem peminjamannya satu kelas diwakili satu orang, yang dipinjem berupa bukubuku paket.

Hampir sama dengan perpustakaan keduanya, alur pelayanan di perpustakaan MAN Y III yaitu mencari buku melalui komputer atau langsung, kalau sudah cocok, mendatangi ke petugas perpus untuk dicatatkan ke dalam peminjaman. Dengan menggunakan kartu anggota. 
Pembinaan/sosialisasi ketiga perpustakaan yaitu untuk siswa dilakukan diawal masuk ketika MOS diperkenalkan tata cara menggunakan perpustakaan serta pembuatan sekaligus pemberitahuan dan pemberlakuan peraturan-peraturan di perpustakaan, atau dengan cara pengarahan langsung secara lisan baik berupa teguran ataupun berupa anjuran kepada siswa yang datang ke perpustakaan. Pembinaan kepada pengguna lain seperti para guru hanya dalam berupa meminta kesadaran para guru atas arti pentingnya perpustakaan sekolah. Pembinaan terhadap petugas perpustakaan dilakukan oleh kepala sekolah langsung berupa arahan atau teguran-teguran kepada petugas perpustakaan dalam menjalankan tugasnya.

\section{Pengawasan}

Pengawasan terhadap perpustaaan MAN Y I dilakukan oleh kepala madrasah datang ke perpustakaan secara langsung dua atau tiga bulan sekali untuk melihatlihat pengaturan letak buku apakah rapi atau tidak. Menurut petugas perpustakaan, pengawasan Kepala madrasah berupa menanyakan bagaimana kondisi perpustakaan madrasah. Perpustakaan MAN Y II pengawasannya berupa kepala madrasah datang ke perpustakaan sebulan sekali atau lebih bergantung dari situasi dan waktu yang ia miliki. Sedang menurut petugas perpustakaan bahwa pengawasan ada dari kepala madrasah namun jarang sekali beliau lakukan. Adapun kepala MAN Y III menyatakan bahwa ada pengawasan mingguan atau bulanan setiap ada waktu longgar, berupa menyaksikan sendiri dan melihat daftar pengunjung. Sedang menurut petugas perpustakaan, pengawasan yang dilakukan kepala madrasah melihat langsung apakah buku sudah diberi katalog atau belum. Pengawasan dapat juga dilakukan dengan cara meminta laporan atas hasil pelaksanaan kegiatan atau laporan pemanfaatan perpustakaan sekolah dan mencocokkan dengan standar atau ukuran yang telah ditetapkan.
Hambatan/Kendala

Kendala perpustakaan MAN Y I yang pertama adalah ruangan, terutama ruang baca. Mengingat pada jam istirahat ketika secara bersamaan siswa memakai ruangan menjadi padat dan ruangan menjadi kurang kondusif untuk membaca. Kedua, Pada saat hari efektif, pengunjung perpustakaan belum bisa terlayani dengan baik. Adapun kendala perpustakaan MAN Y II. Pertama, dari segi fisik bangunan, tempatnya kurang strategis soalnya berada di lantai dua dan tempatnya agak jauh dari ruang kelas. Kedua minat baca siswa sangat kurang, dan yang ketiga petugas perpustakan istilahnya belum ada yang dari jurusan perpustakaan. Kendala yang dihadapi perpustakaan MAN Y III, yang pertama adalah kurangnya tenaga TIK, karena sering dipakai di tempat lain. Yang kedua, kurangnya kesadaran pemustaka/ siswa untuk mengisi presensi pengunjung sehingga sangat banyak pengunjung yang tidak terhitung dalam laporan jumlah pengunjung. Yang ketiga kurangnya honor untuk para petugas yang sesuai dengan UMR.

Upaya

Upaya yang dilakukan selama ini oleh ketiga madrasah tersebut adalah untuk tenaga perpustakaan yang bukan dari jurusan perpustakaan dengan mengadakan diklat-diklat atau seminar tentang manajemen perpustakaan. Untuk sarana perpustakaan yang belum optimal salah satunya yaitu ruang baca dengan menambah diluar ruang perpustakaan sebagai sarana ruang baca. Untuk honor pegawai yang belum UMR yaitu ditambah dengan uang lembur. Untuk kurangnya minat baca siswa, maka guru sering memberikan tugas kepada siswa yang bahan atau materinya hanya ada di perpustakaan.

\section{Simpulan dan Saran}

\section{Simpulan}

1. Manajemen perpustakaan di tiga MAN Yogyakarta yang meliputi aspek: 
a. Perencanaan mencakup pengadaan buku setiap tahunnya.

b. Pengorganisasian perpustakaan pada tiga MAN Y di DIY yaitu, pengorganisasian perpustakaan MAN Y I berada di bawah wakamad humas, pengorganisasian perpustakaan MAN Y II berada di bawah wakamad kurikulum dan pengorganisasian perpustakaan MAN Y III berada di bawah kepala madrasah.

c. Pelaksanaan manajemen di tiga MAN Y mencakup pengadaan, pengolahan, pelayanan dan pembinaan. Pengadaan buku tersebut berasal dari dana DIPA dan Komite. Pengolahan dilakukan secara langsung ketika ada buku baru. Adapun Pelayanan dilakukan ketika jam sekolah masuk dan pembinaan dilakukan oleh kepala madrasah langsung berupa teguran atau saran.

d. Pengawasan dilakukan dengan cara, pertama kepala sekolah langsung datang ke perpustakaan, kedua kepala sekolah minta laporan kepala perpustakaan.

2. Hambatan-hambatan yang dihadapi dalam proses manajemen perpustakaan ketiga MAN Yogyakarta yaitu sebagai berikut: a) tenaga pustakawan kurang, b)sarana perpustakaan kurang maksimal, c) honor tenaga perpustakaan kurang, d) minat baca dan kesempatan berada di perpustakaan kurang. Hal ini menyebabkan manajemen perpustakaan pun belum berjalan secara maksimal.

3. Upaya-upaya yang selama ini dilakukan oleh ketiga perpustakaan adalah sebagai berikut: a) bagi tenaga perpustakaan yang bukan dari jurusan perpustakaan yaitu dengan mengadakan diklat-diklat atau seminar tentang pengelolaan perpustakaan, b) untuk sarana perpustakaan yang belum optimal salah satunya ruang baca ditambah di luar ruang perpustakaan sebagai sarana ruang baca, c. untuk honor pegawai yang belum UMR yaitu ditambah dengan uang lembur, d) minat baca siswa yang kurang, maka guru sering memberikan tugas kepada siswa yang bahan atau materinya hanya ada di perpustakaan.

Saran

Berdasarkan hasil penelitian dalam tesis ini, terdapat beberapa hal yang hendak disampaikan sebagai saran untuk kemajuan perpustakaan di tiga madrasah tersebut terkait dengan manajemen perpustakaan. Saran-saran tersebut adalah:

1. Menambah petugas perpustakaan yang profesional sesuai dengan jurusan perpustakaan. Selain itu ada upaya untuk meningkatkan pegawai perpustakaan dengan cara mengikuti diklat atau seminar tentang perpustakaan yang diadakan di luar sekolah.

2. Menambah sarana prasarana perpustakaan yang memadai.

3. Menambah honor pegawai perpustakaan khususnya yang PTT adalah hal yang sangat penting.

4. Menambah koleksi buku baru dan jam berkunjung. Karena rata-rata kebanyakan bukunya berkaitan dengan pelajaran. Maka perlu ada tambahan koleksi baru sebagai buku penunjang. Selain itu jam istirahat perlu ditambah khusus berkunjung di perpustakaan.

\section{Daftar Pustaka}

Bafadal, I. (2009). Pengelolaan perpustakaan sekolah. Jakarta: Bumi Aksara.

Daft, R.L. (1991). Second edition management. New York: Morgan Russell.

Darmono. (2007). Perpustakaan sekolah: pendekatan aspek manajemen dan tata kerja. Jakarta: Grasindo.

Depdiknas. (2003). Undang-Undang RI Nomor 20, Tahun 2003, tentang Sistem Pendidikan Nasional.

Depdiknas. (2005). Peraturan Pemerintah RI Nomor 19, Tahun 2005, tentang Standar Nasional Pendidikan. 
Handoko, T. H. (1992) Manajemen. Yogyakarta: BPFE.

Moenir, H.A.S. (2003). Manajemen pelayanan umum. Jakarta: Bumi Aksara.

Noe, R.A. (2005) Employe training and development. New York: Mc-GrawHill.

Priyono, S.A. (2006). Perpustakaan atraktif. Jakarta: Grasindo.

Siregar, R.A., (2004). Perpustakaan energi pembangunan bangsa. Medan: USU Press.
Stueart, R.D., \& Moran, B. (2002). Library and information center manajement. Colorado: Libraries Unlimited.

Sutarno, N.S. (2003). Perpustakaan dan masyarakat, Jakarta: Yayasan Obor.

Sugiyono, (2012). Memahami penelitian kualitatif. Bandung: CV. Alfabeta.

Usman, H. (2011). Manajemen, teori, praktik, dan riset pendidikan. Jakarta: Bumi Aksara. 